\title{
WHAT CAN WE LEARN FROM BROWNFIELD DATABASES? EXPLORING SPECIFICS OF THE LOCATION OF BROWNFIELDS IN THE CZECH REPUBLIC
}

\author{
Jaroslav SKRABAL ${ }^{1}$
}

\section{DOI: $10.21163 /$ GT_2020.152.18}

\begin{abstract}
:
The aim of this paper is to advance our understanding of brownfield locations in municipalities and cities situated in the Czech Republic. The data on brownfields was obtained from the National Brownfield Database which is coordinated by the CzechInvest Agency in the Czech Republic. The analysed period of the paper are the years 2018 and 2020. In 2018, 460 brownfields were analysed with an area of 2,334.65 hectares and in 2020 there were 572 abandoned buildings and sites with a total area of 2,320.09 hectares. The data on brownfields are based on the regions of NUTS 3 level. Each brownfield was then divided according to its location, i.e. whether it is located in the centre, in the inner part, outer part or within the development area of the municipalities and cities of the given regions. Based on the obtained data, relative proportions within each region were calculated on the NUTS 3 level for the years 2018 and 2020. It was discovered that brownfields are mostly located in the outer parts of municipalities and cities in both analysed years $(2018,2020)$. Such finding may influence also the possibility of potential brownfield regeneration. Abandoned buildings and sites that are located in the centres or the inner part of municipalities and cities are generally better preconditioned for a potential regeneration and utilization compared to brownfields that are located in the outer parts or on the margins of the cadastral areas of municipalities and cities of the given country.
\end{abstract}

Keywords: Brownfields, NUTS 3, Location, Spatial Analysis, Czech Republic

\section{INTRODUCTION}

Spatial planning is considered to be one of the key tools of how to increase the sustainability of cities and contribute to their development on a global scale (UN, 2015). One of the key aspects of sustainable spatial planning is sustainable land use, i.e. more deliberate approach towards which type of land is used for the development of cities. It is particularly necessary with cities with a growing population to take a decision which areas are most suitable for future development. A promising approach seems to be a re-development of formerly used sites that are now vacant, such as brownfields, for new projects of city developments, especially the ones that are situated in central localities (Bartke \& Schwarze, 2015). Brownfields are defined as ,any land which was formerly used or developed and is now not fully used, even though it can be partially occupied or used as well as unoccupied, vacant or contaminated" (Alker et al., 2000). Another definition emphasizes the need for location and development and it indicates that brownfields are predominantly located in developed urban areas and require some intervention in order to be used repeatedly (CABERNET, 2006).

Brownfields represent significant social and environmental issues across the world (Thornton et al., 2007), and are recognized by the international association (OSN, 2015) and the European Union (EC, 2012). Brownfields are of various origin, are distributed across the entire country, yet they represent a significant issue in densely urbanized areas, such as cities in particular (Burinskiene et al., 2017). Abandoned buildings and sites are an integral part of cities in Central Europe (Tureckova et al., 2017). Brownfields that are located in the inner city, in the vicinity of the inner city or near other municipal subcentres are generally well-connected with the current technical and social infrastructures (Koch et al., 2018). The level of brownfield regeneration reflects the cultural and

\footnotetext{
1 School of Business Administration in Karvina, Silesian University in Opava, Univerzitni Nam. 1934/3, 73340 Karvina, Czech Republic, skrabal@opf.slu.cz
} 
economic development of the country, region, city or village as it reflects the strategies of sustainable development of sites (Wedding \& Crawford-Brown, 2007).

Tools for dealing with disagreements between the interests of involved parties and the aims of sustainable development are rare (Bartke et al., 2016). Former studies showed that the location of brownfields in the inner city is influenced by the type of regeneration (Bjelland, 2004; Temelova, 2007). The type of regeneration may or may not reflect the opinions of local inhabitants (De Sousa, 2006) and sustainability (Bleicher \& Gross, 2010). However, while planning brownfield regeneration, opinions of the local inhabitants should be taken into consideration (Meyer \& Lyons, 2000), especially if the regeneration is co-financed using public funds (Rizzo et al., 2015). A major argument in favour of brownfield regeneration is the necessity to retain the compactness of cities and thus prevent their uncontrolled and non-regulated expansion (Tureckova et al., 2018). The planning of brownfield regeneration according to the principles of sustainable development presents a significant challenge, especially with rural brownfields that have small chances of attracting private investment (Sardinha, Craveiro \& Milheiras, 2013). The balance between the development of cities and countryside is not only a common trend, but it is also a common objective for all countries in order to achieve sustainable integration between cities and countryside. Even though the countries across the world have a distinct history, culture, ideology, economic growth and other aspects, they also suffer from uneven growth between municipal and rural areas (Abrham, 2011; Dong et al., 2011; Gurrutxaga, 2013; Zitti et al., 2017). In the past, the rural countryside was perceived mainly as a tool for agricultural production. One of the most important values of the landscape was thus soil fertility, accessibility of field and suitability of the field for agricultural purposes and use of machines (Prishchepov et al., 2012). The current approach allows for agricultural, residential and tourist functions of the landscape. One of the most important fucntions of the landscape are the characteristic of the landscape, aesthetics of the landscape, diversity and function of the environment. Some parts of rural landscape are undergoing serious changes, especially the landscape in the vicinity of large cities (Stastna et al., 2018). Despite all this effort, the loss of agricultural soil in certain European countries is still rather dramatic. Agricultural land needs to be protected against several threats. This is deeply influenced by the development of agriculture and its adaptation to the changing domestic as well as global driving forces, including the volatility of the market, climate disruption of global food supply and a growing demand for local foodstuffs (Connell et al., 2013).

Urbanization belongs to one of the biggest trends of this century across the world, which means that the most important factor that changes urban landscape is the expansion of built-up sites, which is connected to urban sprawl (Luck \& Wu, 2002; Van Eetvelde \& Antrop, 2004). Urban sprawl has plenty of negative impacts on the environment, such as higher energy consumption, higher air pollution, reduced regional open space, loss of agricultural land, reduced species variety and fragmentation of ecosystems (Johnson, 2001). Green areas suitable for recreation must be preserved withing urban regions as by creating large parks, green belts and local recreational areas mental and physical well-being of inhabitants of the cities is improved (von Hertzen, Hanski \& Haahtela, 2011).

Brownfields remain one of the biggest challenges of contemporary urbanists and developers (Frantal et al., 2015). With ongoing global economic stagnation, many industrial sectors either disappear or are moved to countries with lower labour costs - new brownfields emerge and their sustainable development is still restricted by many obstacles (Alexandrescu et al., 2014; Frantal \& Martinát, 2013; Ganser \& Williams, 2007; Payne, 2013; Vojkovska et al., 2013). As global economic stagnation continues, the investments fall and many industries disappear or are moved to countries with lower labour costs - new brownfields emerge, and their sustainable redevelopment is still constrained by many barriers and associated with several dilemmas (Alexandrescu et al., 2014; Frantal \& Martinát, 2013; Ganser \& Williams, 2007; Payne, 2013; Vojkovska et al., 2013). Abandoned buildings and sites left without any effort to find some alternative use prevent a further development of built-up sites, unfavourably influence the environment and have a bad impact on the given region in general (Tureckova et al., 2019).

The aim of the paper is to better understand the shift in the location brownfields in municipalities and cities in the Czech Republic as is evidenced in official brownfield databases in the years 2018 
and 2020. The paper is structured as follows: after the introduction, a chapter follows focusing on data on brownfields in the Czech Republic, focusing particularly on their number and location. The next chapter deals with the methodology of the contribution. The fourth chapter deals with the results that were achieved by the author. The conclusion at the end summarizes existing findings.

\section{DATA}

The second chapter focuses on the number and size of brownfields in the Czech Republic. The Czech Republic is situated in Central Europe and has an area of 7,886,600 hectares. Currently (2020), approximately 10,694,364 inhabitants are living in the Czech Republic (CSO, 2020). There are 14 regions of NUTS 3 level (Eurostat Database, 2020). The Figure below (Fig. 1) displays the mentioned regions of NUTS 3 level in the Czech Republic.

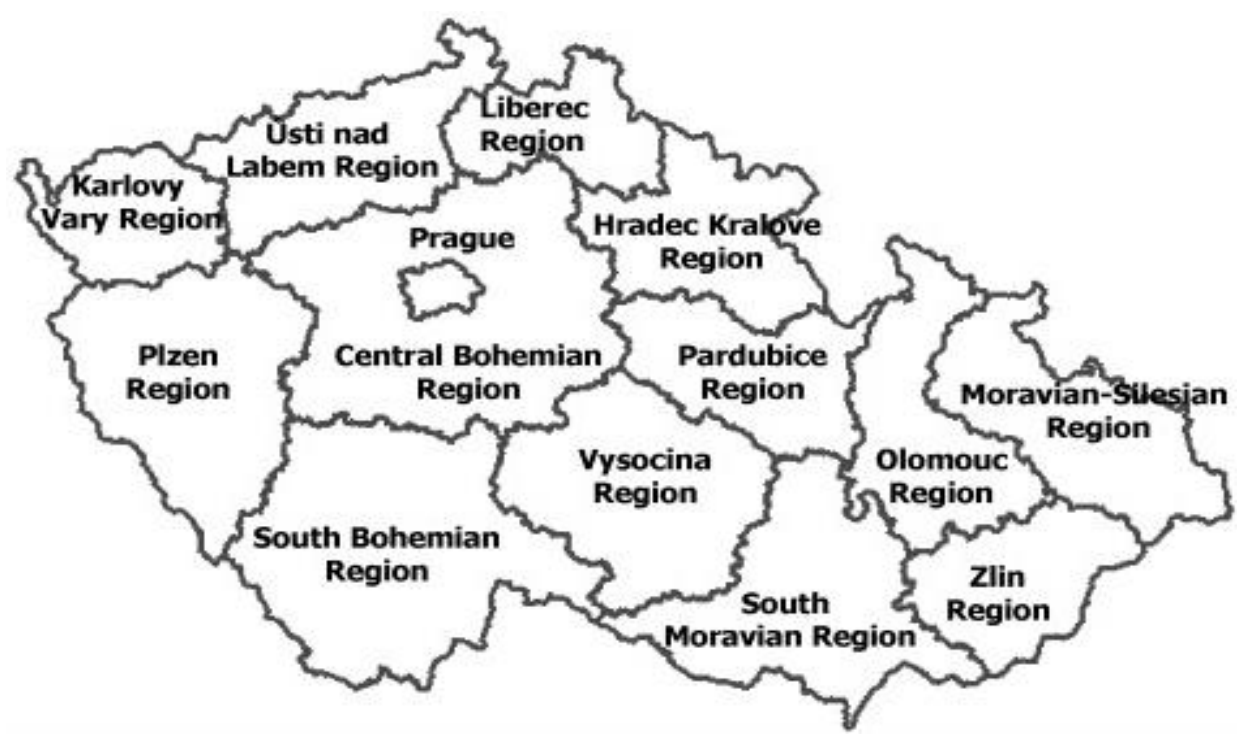

Fig. 1. NUTS 3 regions in the Czech Republic (Source: Eurostat, 2020).

For the purposes of the paper, the data on brownfields was obtained from the National Brownfield Database which is coordinated by the CzechInvest Agency in the Czech Republic. Prague is not included in the results as there is only one abandoned building registered according to the database and it does not reflect the reality and problematics of the brownfield incidence in the capital city of Prague. In 2018, a total of 460 abandoned buildings and sites with an area of 2,335 hectares were registered. In 2020, the number of brownfields increased to 572 , yet the area was reduced to 2,320 hectares. It follows that the number of registered abandoned building and sites between the two analysed years increased by 112 , yet the total area decreased by 15 hectares.

In the Czech Republic, there are approximately 10 to 12 thousand brownfields with an area of 25 to 35 thousand hectares (National Brownfield Regeneration Strategy, 2019). The reason for the nonexistence of these buildings and sites in the National Brownfield Database is influenced by the owners of the individual land and sites who are not interested in registering the involved sites as brownfields.

The table below (Table 1) focuses on information regarding the area of individual regions of NUTS 3 level in the Czech Republic, on the number of brownfields in 2018 and 2020 and their area. The highest occurrence of these abandoned buildings and sites is predominantly in Ústí nad Labem Region, Liberec Region and South Moravian Region. The largest area of brownfields is recorded mainly in Central Bohemian Region, Ústí nad Labem Region and Moravian-Silesian Region. 
Table 1.

The number of brownfields and their size in individual regions of NUTS 3 level.

\begin{tabular}{|c|c|c|c|c|c|}
\hline NUTS 3 & $\begin{array}{l}\text { Area of the } \\
\text { region in } \\
\text { (ha) }\end{array}$ & $\begin{array}{c}\text { Number of } \\
\text { brownfields } \\
\quad(2018)\end{array}$ & $\begin{array}{c}\text { Area of } \\
\text { brownfields } \\
\text { in (ha) } \\
(\mathbf{2 0 1 8 )}\end{array}$ & $\begin{array}{c}\text { Number of } \\
\text { brownfields } \\
(2020)\end{array}$ & $\begin{array}{c}\text { Area of } \\
\text { brownfields } \\
\text { in (ha) } \\
(2020)\end{array}$ \\
\hline $\begin{array}{c}\text { Karlovy Vary } \\
\text { Region }\end{array}$ & 331,400 & 32 & 216 & 43 & 183 \\
\hline $\begin{array}{c}\text { Ústí nad } \\
\text { Labem Region }\end{array}$ & 533,500 & 62 & 209 & 80 & 220 \\
\hline $\begin{array}{l}\text { Liberec } \\
\text { Region }\end{array}$ & 316,300 & 61 & 188 & 58 & 166 \\
\hline $\begin{array}{l}\text { Pardubice } \\
\text { Region }\end{array}$ & 451,900 & 28 & 66 & 25 & 35 \\
\hline $\begin{array}{l}\text { Hradec } \\
\text { Králové } \\
\text { Region } \\
\end{array}$ & 475,900 & 24 & 110 & 34 & 166 \\
\hline $\begin{array}{l}\text { Vysočina } \\
\text { Region }\end{array}$ & 679,600 & 24 & 29 & 30 & 35 \\
\hline $\begin{array}{c}\text { South } \\
\text { Bohemian } \\
\text { Region } \\
\end{array}$ & $1,005,700$ & 33 & 74 & 37 & 56 \\
\hline Plzeň Region & 756,100 & 24 & 103 & 34 & 195 \\
\hline $\begin{array}{c}\text { Central } \\
\text { Bohemian } \\
\text { Region }\end{array}$ & $1,101,500$ & 30 & 774 & 38 & 768 \\
\hline $\begin{array}{l}\text { Olomouc } \\
\text { Region }\end{array}$ & 526,700 & 35 & 160 & 44 & 107 \\
\hline $\begin{array}{c}\text { South } \\
\text { Moravian } \\
\text { Region } \\
\end{array}$ & 718,800 & 52 & 186 & 67 & 122 \\
\hline Zlín Region & 396,400 & 15 & 18 & 13 & 8 \\
\hline $\begin{array}{c}\text { Moravian- } \\
\text { Silesian } \\
\text { Region }\end{array}$ & 542,700 & 40 & 203 & 69 & 260 \\
\hline Total & $7,836,500$ & 460 & 2,335 & 572 & 2,320 \\
\hline
\end{tabular}

Source: CzechInvest, 2018; 2020, adopted.

Another table (Table 2) describes the share of the area of brownfields on the area of the given region where the abandoned building or site is located. The data on the area of brownfields and regions is adopted from the previous table (Table 1). Information in the table below (Table 2) is in relative numbers. In both years $(2018,2020)$, the largest share of brownfield area on the area of the given region is mainly in Central Bohemian Region, Karlovy Vary Region and Liberec Region. In 2018, the total proportion of the area of brownfield sites registered in the National Brownfield Database in the Czech Republic was $0.0298 \%$ in relative terms; two years later, the proportion was $0.0296 \%$. It should be emphasized that the proportion of acreage involved is actually larger, as most abandoned properties and sites are not on the register. 
Table 2.

Share of the area of brownfields on the area of individual regions of NUTS 3 level.

\begin{tabular}{|c|c|c|}
\hline NUTS 3 & $\begin{array}{c}\text { Share of BF area in NUTS } 3 \\
\text { region area }(2018) \text { in \% }\end{array}$ & $\begin{array}{c}\text { Share of BF area in NUTS } 3 \\
\text { region area }(2020) \text { in } \%\end{array}$ \\
\hline Karlovy Vary Region & 0.0651 & 0.0551 \\
\hline Ústí nad Labem Region & 0.0391 & 0.0413 \\
\hline Liberec Region & 0.0593 & 0.0523 \\
\hline Pardubice Region & 0.0146 & 0.0088 \\
\hline Hradec Králové Region & 0.0232 & 0.0349 \\
\hline Vysočina Region & 0.0037 & 0.0050 \\
\hline South Bohemian Region & 0.0074 & 0.0056 \\
\hline Plzeň Region & 0.0136 & 0.0257 \\
\hline Central Bohemian Region & 0.0700 & 0.0698 \\
\hline Olomouc Region & 0.0302 & 0.0202 \\
\hline South Moravian Region & 0.0258 & 0.0169 \\
\hline Zlín Region & 0.0044 & 0.0020 \\
\hline Moravian-Silesian Region & 0.0373 & 0.0480 \\
\hline Total & 0.0298 & 0.0296 \\
\hline
\end{tabular}

Source: based on own survey, 2020.

\section{METHODOLOGY}

The third chapter is focused on the methodology of the paper. The aim of the paper is to better understand the shift in the location brownfields in municipalities and cities in the Czech Republic as is evidenced in official brownfield databases in the years 2018 and 2020. The reason for choosing this topic is that the author wishes to locate the abandoned buildings and sites within the structure of municipalities and cities in individual regions of the Czech Republic. For the purposes of the paper, the data on brownfields from 2018 and 2020 was obtained from the National Brownfield Database. As it was mentioned above, in 2018, 460 abandoned buildings and sites were registered and in 2020, it was 572.

For the purposes of the paper, brownfields were localized using an exact location of brownfields that are mentioned with every registered abandoned building and site in the database. The data on brownfields is based on the regions of NUTS 3 level. Each brownfield was then divided according to its location, i.e. whether it is located in the centre, in the inner part, outer part or within the development area of the municipalities and cities of the given regions. Based on the obtained data, relative shares within individual regions on the NUTS 3 level were calculated for the years 2018 and 2020. The table below (Table 3) shows the characteristics of the parts. 
Table 3.

The characteristic of parts

\begin{tabular}{|c|c|}
\hline Centre & $\begin{array}{l}\text { - The center, or also the central zone, is the accumulation of all functions, areas } \\
\text { prevail here and areas of higher public amenities serving residents. } \\
\text { The functional composition is accompanied by a varied structure of public spaces } \\
\text { made up of equally varied constructions with a range of architectural values. }\end{array}$ \\
\hline Inter Part & $\begin{array}{l}\text { - This section is mainly characterised by functionally mixed multi-storey } \\
\text { development with a higher proportion of built-up areas. } \\
\text { Usually one of the basic functions prevails in these parts of cities, most often } \\
\text { housing. }\end{array}$ \\
\hline Outer part & $\begin{array}{l}\text { - Within this section, it is a territory that is mixed. } \\
\text { - This applies not only in functional but also spatial terms. } \\
\text { - The mixture of functional areas and objects is supported by a loose-knit form of } \\
\text { construction mostly of individual architectural design and without the ambition of } \\
\text { creating a public space or an architectural file. }\end{array}$ \\
\hline $\begin{array}{c}\text { Development } \\
\text { area }\end{array}$ & $\begin{array}{l}\text { - Immediately following link into stoppable territory. } \\
\text { - } \quad \text { However, these are hugely important areas and spaces that convey the optimal } \\
\text { transition of urbanised environments and free economically exploited landscapes. }\end{array}$ \\
\hline
\end{tabular}

Source: URR, 2020; adopted.

\section{RESULTS}

The next part of the paper will be dealing with the localization of brownfields. First, the results for 2018 and 2020 in relative numbers will be mentioned and at the end of this chapter, the summary of the results will be performed. The table below (Table 3) displays the results of the localization of abandoned buildings and sites in 2018 in individual regions on NUTS 3 level in the Czech Republic. It can be seen from the table that the majority of brownfields in all analyzed regions of the country are largely located in the outer parts of municipalities and cities. The majority of such abandoned buildings and sites are located in Olomouc Region, Moravian-Silesian Region and Central Bohemian Region. The second largest group is represented by abandoned buildings and sites located in the outer parts of municipalities and cities. The largest number of localized brownfields in this group are mainly in Karlovy Vary Region. Another group is represented by abandoned buildings and sites that are located in the inner parts of municipalities and cities. The largest number of localized abandoned buildings and sites in this group is predominantly in Hradec Králové Region. Brownfields that are located in the centres of municipalities and cities belong to the last group. It is evident that in this group the largest localization is mainly in Zlín Region.

The following table (Table 4) displays the results of localization of brownfields in 2020. The largest relative shares of localized abandoned buildings and sites are mainly in the outer parts of municipalities and cities, such as in 2018 (see Table 3). Within this group, Moravian-Silesian Region, Pardubice Region and Olomouc Region dominate. Next, it was discovered that the second group of brownfields is represented by the ones located in the inner parts of municipalities and cities. Here, Karlovy Vary Region, South Bohemian Region and Central Bohemian Region dominate. The third part involves abandoned buildings and sites that are located on the margins of cadastral areas of municipalities and cities. This includes mainly Liberec Region and Vysočina Region. The last group includes abandoned buildings and sites that are localized in the centres of municipalities and cities. This group includes mainly brownfields localized in Zlín Region, Ústí nad Labem Region and Central Bohemian Region. 
Table 4.

Localization of brownfields within the regions on NUTS 3 level in the Czech Republic in 2018 in \%.

\begin{tabular}{|c|c|c|c|c|}
\hline NUTS 3 & Centre & Inner part & Outer part & Development area \\
\hline Karlovy Vary Region & 0 & 6.3 & 65.6 & 28.1 \\
\hline Ústí nad Labem Region & 14.5 & 12.9 & 66.1 & 6.5 \\
\hline Liberec Region & 8.2 & 21.3 & 59 & 11.5 \\
\hline Pardubice Region & 10.7 & 17.9 & 64.3 & 7.1 \\
\hline Hradec Králové Region & 16.7 & 25 & 45.8 & 12.5 \\
\hline Vysočina Region & 17.4 & 21.7 & 52.2 & 8.7 \\
\hline South Bohemian Region & 12.1 & 18.2 & 51.5 & 18.2 \\
\hline Plzeň Region & 16.7 & 12.4 & 54.2 & 16.7 \\
\hline $\begin{array}{l}\text { Central Bohemian } \\
\text { Region }\end{array}$ & 6.7 & 13.3 & 70 & 10 \\
\hline Olomouc Region & 0 & 11.8 & 76.4 & 11.8 \\
\hline South Moravian Region & 15.7 & 9.8 & 56.9 & 17.6 \\
\hline Zlín Region & 21.4 & 7.1 & 57.1 & 14.4 \\
\hline $\begin{array}{l}\text { Moravian-Silesian } \\
\text { Region }\end{array}$ & 5.3 & 2.5 & 71.1 & 21.1 \\
\hline
\end{tabular}

Source: based on own survey, 2020.

Table 5.

Localization of brownfields within the regions on NUTS 3 level in the Czech Republic in 2020 in \%.

\begin{tabular}{|l|c|c|c|c|}
\hline \multicolumn{1}{|c|}{ NUTS 3 } & Centre & Inner part & Outer part & Development area \\
\hline Karlovy Vary Region & 9.3 & 32.6 & 41.9 & 16.2 \\
\hline Ústí nad Labem Region & 16.5 & 21.5 & 50.6 & 11.4 \\
\hline Liberec Region & 6.9 & 22.4 & 50 & 20.7 \\
\hline Pardubice Region & 12 & 20 & 64 & 4 \\
\hline Hradec Králové Region & 14.7 & 17.7 & 52.9 & 14.7 \\
\hline Vysočina Region & 13.8 & 17.2 & 48.3 & 20.7 \\
\hline South Bohemian Region & 8.1 & 27.1 & 45.9 & 18.9 \\
\hline Plzeň Region & 14.7 & 23.5 & 52.9 & 14.2 \\
\hline $\begin{array}{l}\text { Central Bohemian } \\
\text { Region }\end{array}$ & 15.8 & 26.3 & 44.7 & 13.4 \\
\hline Olomouc Region & 7 & 20.9 & 58.1 & 0 \\
\hline South Moravian Region & 13.4 & 19.5 & 53.7 & 14.9 \\
\hline Zlín Region & 16.7 & 25 & 58.3 & 64.2 \\
\hline $\begin{array}{l}\text { Moravian-Silesian } \\
\text { Region }\end{array}$ & 7.5 & 13.4 & S.9 & 14 \\
\hline
\end{tabular}

Source: based on own survey, 2020.

The figure below (Fig. 2) presents the complete results of the localization of brownfields in the Czech Republic in 2018 and 2020. The values shown in the chart below show the relative expression of localized abandoned objects and areas in given parts (Center, Inter part, Outer part, Development area) following the period. It is evident from the figure that within the analysed period the abandoned buildings and sites are to be found mainly in the outer parts of municipalities and cities. 
During the year 2018, it involves $61.7 \%$ of localized brownfields in the area of the Czech Republic. In 2020, it oscillates around 52.3\%. The second group is represented by abandoned buildings and sites located in the inner parts of municipalities and cities. In 2018, the relative number was $13.9 \%$ and in 2020, it reached $21.4 \%$. It was discovered that the third group was represented by brownfields located in the outer parts of municipalities and cities where the relative number was $13.9 \%$ in 2018 and in 2020, the number was similar to the previously analysed year, i.e. $14 \%$. The last group is formed by abandoned buildings and sites localized in the centres of municipalities and cities. The relative number reached $10.5 \%$ in 2018 and increased to $12.3 \%$ in 2020.

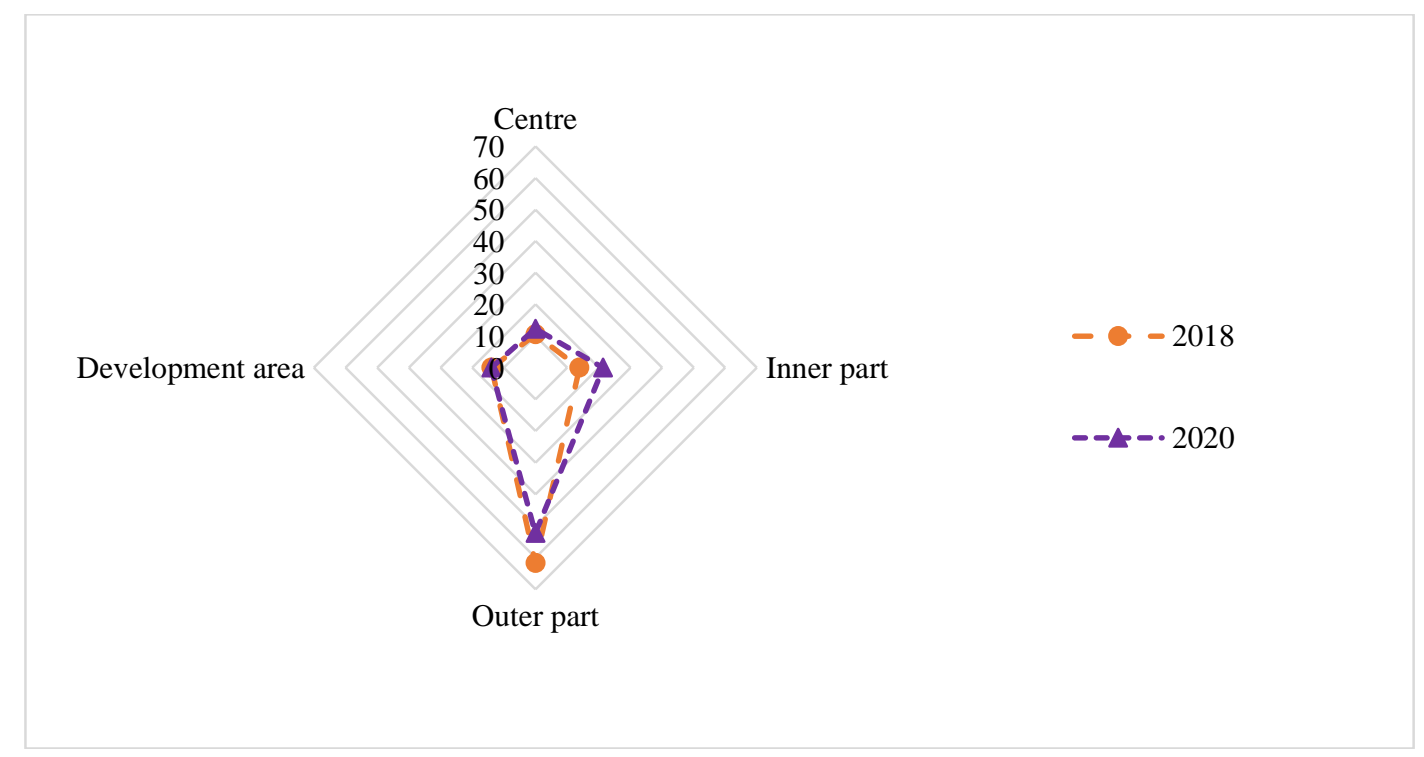

Fig. 2. The resulting evaluation of localized brownfields for the years 2018 and 2020 in the Czech Republic.

(Source: based on own survey).

\section{CONCLUSION}

The paper dealt with the issue of brownfields in individual regions of NUTS 3 level in the Czech Republic based on the localization using an exact location of brownfields. The aim of the paper was to better understand the shift in the location brownfields in municipalities and cities in the Czech Republic as is evidenced in official brownfield databases in the years 2018 and 2020. The analysed period of this contribution covered the years 2018 and 2020. It was discovered that the largest number of abandoned buildings and sites is mostly in Ústí nad Labem Region, Liberec Region and South Moravian Region.

The paper then analysed the area of NUTS 3 regions in the Czech Republic and the area of the individual abandoned buildings and sites in the analysed years. It was discovered that the largest share of brownfield area on the area of the given region is primarily in Central Bohemian Region, Karlovy Vary Region and Liberec Region. In addition, the author examined the localization of abandoned buildings and areas based on an exact location of brownfields that are quoted with each registered brownfield in National Brownfield Database.

It was discovered that brownfields are mostly located in the outer parts of municipalities and cities in both analysed years $(2018,2020)$. 
The mentioned finding may also impact potential brownfield regeneration. Abandoned buildings and sites that are located in the centres or the inner parts of municipalities and cities generally stand a better chance to be potentially regenerated and reused. Abandoned buildings and sites located in the outer parts of municipalities and cities are rather little attractive for potential investors and developers who are interested in the opportunity to regenerate and reuse brownfields. These include primarily areas more distant from the centres that are of no added value for the investors.

Generally, it can be stated that the most attractive localities with the biggest chance to be regenerated are the ones in the vicinity of the centres with accessible transport infrastructure. There is a huge difference regarding the utilization opportunities of abandoned buildings and sites depending on whether they are located in the cities or municipalities. Cities are more suitable for brownfield regeneration than municipalities. Potential investors and developers primarily search abandoned buildings and sites that are located near the city centres as these are attractive due to their location and transport accessibility. By contrast, brownfields located within municipalities do not feature any added value for their potential investors regarding their reuse.

The paper managed to locate brownfields within the structure of municipalities and cities in individual regions of the Czech Republic based on an exact location of brownfields. As it was mentioned above, abandoned buildings and sites are primarily located in the outer parts of municipalities and cities. Here, they can be possibly regenerated and reused provided that the potential investors or developers are interested in those particular brownfields.

As part of the contribution, it should be noted that there are limited data sources that also influence the existence of the results. As mentioned in the post above, the registration of abandoned objects and sites in the National Brownfield Database in the Czech Republic is influenced by the owners of the brownfield sites concerned, who are not interested in the registration and declaration of the brownfield properties. This may also have an effect on the results achieved in the post.

\section{ACKNOWLEDGMENT}

This paper was supported by the project SGS/20/2019 "Brownfields in urban and rural space: geographic, economic, business and public administrative contexts and their importance for regional development (BURAN 2)".

\section{R E F E R E N C E S}

Abrham, J. (2011) Rural development and regional disparities of the new EU Member State. Agricultural Economics, 57 (6), 288-296.

Alexandrescu, F., Martinat, S., Klusacek, P. \& Bartke, S. (2014) The path from passivity toward entrepreneurship public sector actors in brownfield regeneration processes in Central and Eastern Europe. Organization \& Environment, 27 (2), 181-201.

Alker, S., Joy, V., Roberts, P. \& Smith, N. (2000) The definition of brownfield. Journal of Environmental Planning and Management, 43 (1), 49-69.

Bartke, S. \& Schwarze, R. (2015) No perfect tools: Trade-offs of sustainability principles and user requirements in designing support tools for land-use decisions between greenfields and brownfields. Journal of Environmental Management, 153, 11-24.

Bartke, S., Stanislav, M., Klusacek, P., Pizzol L., Alexandrescu, F., Frantal B., Critto, A. \& Zabeo, A. (2015) Targeted selection of brownfields from portfolios for sustainable regeneration: User experiences from five cases testing the Timbre Brownfield Prioritization Tool. Journal of Environmental Management, 184 (1), 94-107. 
Bjelland, M. D. (2004) Brownfield Sites in Minneapolis-St. Paul: The Interwoven Geographies of Industrial Disinvestment and Environmental Contamination. Urban Geography, 25 (7), 631-657.

Bleicher, A. \& Gross, M. (2010) Sustainability assessment and the revitalization of contaminated sites: operationalizing sustainable development for local problems. International Journal of Sustainable Development \& World Ecology, 17 (1), 57-66.

Burinskiene, M., Bielinskas, V., Podviezko, A., Gurskiene, V. \& Maliene, V. (2017) Evaluating the significance of criteria contributing to decision-making on brownfield land redevelopment strategies in urban areas. Sustainability, 9 (5), 759-776.

CABERNET (2006). Sustainable brownfield regeneration: CABERNET network report Nottingham: University of Nottingham.

Connell, D. J., Bryant, C. R., Caldwell, W. J., Churchyard, A., Cameron, G., Johnston, T., Margulis, M. E., Ramsey, D. \& Marois, C. (2013) Food sovereignty and agricultural land use planning: the need to integrate public priorities across jurisdictions. Journal of Agriculture, Food Systems, and Community Development, 3 (4), 117-124.

CSO (2020). - Czech Statistical Office. Avaiable from: https://www.czso.cz/csu/czso/home [Accessed July 2020].

De Sousa, C. A. (2006) Unearthing the benefits of brownfield to green space projects: an examination of project use and quality of life impacts. Local Environment, 11 (5), 577-600.

Dong, X., Song, S. \& Zhu, H. (2011) Industrial structure and economic fluctuation evidence from China. The Social Science Journal, 48 (3), 468-477.

EC (2012). Guidelines on best practice to limit, mitigate or compensate soil sealing. SWD (2012) 101 final.

Frantal, B., Greer-Wrootten, B., Klusacek, P., Krejci, T., Kunc, J. \& Martinat, S. (2015). Exploring spatial patterns of urban brownfields regeneration: The case of Brno, Czech Republic. Cities, 44, 9-18.

Frantal, B. \& Martinát, S. (2013) Brownfields: A geographical perspective. Moravian Geographical Reports, 21 (2), 2-4.

Ganser, R. \& Williams, K. (2007). Brownfield development: Are we using the right targets? Evidence from England and Germany. European Planning Studies, 15 (5), 603-622.

Gurrutxaga, M. (2013) Changes in rural-urban sex ratio differences in the young professional age group as an indicator of social sustainability in rural areas: a case study of continental Span, 2000-2010. Area, 45 (3), 337-347.

von Hertzen, L., Hanski, I. \& Haahtela, T. (2011) Natural immunity. EMBO Reports, 12 (11), 1089-1093.

Johnson, M. P. (2001) Environmental impacts of urban Sprawl: A survey of the literature and proposed research agenda. Environment and Planning A: Economy and Space, 33 (4), 717-735.

Koch, F., Bilke, L., Helbig, C. \& Schlink, U. (2018) Compact or cool? The impact of brownfield redevelopment on inner-city micro climate. Sustainable Cities and Society, 38, 31-41.

Luck, M. \& Wu, J. G. (2002) A gradient analysis of urban landscape pattern: A case study from the phoenix metropolitan region, Arizona, USA. Landscape Ecology, 17 (4), 327-339.

Meyer, P. B. \& Lyons, T. S. (2000) Lessons from private sector Brownfield redevelopers -planning public support for urban regeneration. Journal of the American Planning Association, 66 (1), 46-57.

MPO (2020). Narodni strategie regenerací brownfieldu 2019-2024. Available from: https://www.mpo.cz/cz/podnikani/dotace-a-podpora-podnikani/podpora-brownfieldu/narodni-strategieregeneraci-brownfieldu-2019-2024--248322/ [Accessed July 2020].

Payne, S. (2013) Pioneers, pragmatists and sceptics: Speculative house builders and brownfield development in the early twenty-first century. Town Planning Review, 84 (1), 37-62.

Prishchepov, A. V., Radeloff, V., Baumann, M., Kuemmerle, T. \& Müller, D. (2012) Effects of institutional changes on land use: agricultural land abandonment during the transition from state-command to marketdriven economies in post-Soviet Eastern Europe. Environmental Research Letters, 7 (2), 68-85.

Rizzo, E., Pesce, M., Pizzol, L., Alexandrescu, F. M., Giubilato, E., Critto, A., Marcomini, A. \& Stephan. B. (2015) Brownfield regeneration in Europe: identifying stakeholder perceptions, concerns, attitudes and information needs. Land Use Policy, 48, 437-453. 
Sardinha, I. D., Craveiro, D. \& Milheiras, S. (2013) A sustainability framework for redevelopment of rural brownfields: stakeholder participation at SÃO DOMINGOS mine, Portugal. Journal of Cleaner Production, 57, 200-208.

Stastna, M., Vaishar, A., Vavrouchova, H., Masícek, T. \& Perinkova, V. (2018) Values of a suburban landscape: Case study of Podoli u Brna (Moravia), The Czech Republic. Sustainable Cities and Society, 40, 383-393.

Temelova, J. (2007) Flagship developments and the physical upgrading of the post-socialist inner city: the golden angel project in Prague. Geografiska Annaler: Series B, Human Geography, 89 (2), 169-181.

Thornton, G., Franz, M., Edwards, D., Pahlen, G. \& Nathanail, P. (2007) The challenge of sustainability: incentives for brownfield regeneration in Europe. Environmental Science \&Policy, 10 (2), 116-134.

Tureckova, K., Martinat, S., Skrabal, J., Chmielova, P. \& Nevima, J. (2017) How local population perceive impact of brownfields on the residential property values: some remarks from postindustrial areas in the Czech Republic. Geographia Technica, 12 (2), 150-164.

Tureckova, K., Nevima, J., Skrabal, J. \& Martinat, S. (2018) Uncovering patterns of location of brownfields to facilitate their regeneration: Some remarks from the Czech Republic. Sustainability, 10 (6), $224-234$.

Tureckova, K., Nevima, J. Skrabal, J. \& Tuleja. P. (2019) Categorization of Impact of the Selected Variables for Potential Brownfield Regeneration in the Czech Republic by Means of Correspondence Analysis. Geographia Technica, 14 (2), 120-130.

UN (2015). - Sustainable development goals: 17 goals to transform our world. Available from: http://www.un.org/sustainabledevelopment/ [Accessed July 2020].

URR (2020) - Institute For Spatial Development. Available from: www.uur.cz/principy/pap/KapitolaB/B3311_MestaSidla_20061206.pdf+\&cd=1\&hl=cs\&ct=clnk\&gl=cz [Accessed July 2020].

Van Eetvelde, V. \& Antrop, M. (2004) Analysing structural and functional changes of traditional landscapes two examples from Southern France. Landscape and Urban Planning, 67 (1-4), 79-95.

Vojkovska, D., Vojvodíkova, B. \& Maceckova, B. (2013) Underused land, brownfields, future use and effects BROWNTRANS Project outputs. WIT Transactions on Ecology and the Environment, 173, $205-216$.

Wedding, G.C. \& Crawford-Brown, D. (2007) Measuring site-level success in brownfield redevelopments: a focus on sustainability and green building. Journal of Environmental Management, 85 (2), 483-495.

Zitti, M., Efstathios, G \& Salvati, L. (2017) Beyond the "Divided City ": a manifesto for spatially-balanced, sprawl-free post-crisis metropolises. Review of Applied Socio-Economic Research, 13 (1), 95-109. 